\title{
Impact of car free day on foyer building environment
}

\author{
Syed Zain Ullah Gharsheen ${ }^{1}$, Zaiton Haron ${ }^{1, *}$, Khairulzan Yahya ${ }^{1}$, Nadirah Darus ${ }^{1}$, \\ Muhamad Azril Hezmi ${ }^{2}$, and Ain Naadia Mazlan ${ }^{1}$ \\ ${ }^{1}$ Department of Structure and Materials, Faculty of Civil Engineering, Universiti Teknologi Malaysia, \\ 81310 Johor Bahru, Johor, Malaysia \\ ${ }^{2}$ Department of Geotechnic and Transportation, Faculty of Civil Engineering, Universiti Teknologi \\ Malaysia, 81310 Johor Bahru, Johor, Malaysia
}

\begin{abstract}
Universiti Teknologi Malaysia has been organizing the car-free day (CFD) on the campus since 2016 among others to reduce air pollution and improve environmental awareness among campus community. This study aims to determine the effect of the car-free day on two foyer's building environment with three objectives; to determine the variation of traffic volume, to assess the $\mathrm{CO}_{2}$ concentration and noise level variation, and to evaluate the impact of traffic volume variation on $\mathrm{CO}_{2}$ concentration and noise level in building. Two different locations of building are selected; inside and outside CFD. Traffic volumes on the nearby roads are counted and $\mathrm{CO}_{2}$ concentration and noise level at the foyer of the selected building are recorded i.e 8:00-3:00 pm, both during CFD and NCFD at each location. The significant impact of traffic compositions on $\mathrm{CO}_{2}$ and noise level variation are evaluated by using the statistical method including T-test, simple and multiple regression analysis with $\mathrm{R}^{2}$ and ANOVA test, with significant level of $5 \%$. The results show that the implementation of CFD has good and adverse impacts on building environment. The good is CFD reduces traffic volumes up to $80 \%$, and significantly reduce both $\mathrm{CO}_{2}$ and noise level at building located in car free zone. At the selected site, the reduction of $\mathrm{CO}_{2}$ is $13.57 \pm 4.87 \mathrm{ppm}$ per hour and the reduction of noise level is $4.7 \pm 1.74 \mathrm{dBA}$. During CFD, the concentration of $\mathrm{CO} 2$ is significantly governed by the volume of the bus while noise level is significantly correlated with the total volume of traffic. Reduction of noise level is significantly related with decrease of volume of lorries on road. On the other hand, CFD causes adverse impact on building environment as there is significant increase in traffic volume, noise level and $\mathrm{CO}_{2}$ concentration at a selected site outside of CFD zone. The traffic volume increase up to $82 \%$ which dominantly characterized by car and motorbikes. These results in increment of noise level by $1.77 \pm 1.37 \mathrm{dBA}$ and sharp increase of $\mathrm{CO}_{2}$ more than $9999 \mathrm{ppm}$ after the first 3 hours of CFD and remain the same values until end of CFD which may be not acceptable for human comfort. Result from this study shows that CFD improve the environment in building located at CFD zone but worsen the building environment in NCFD.
\end{abstract}




\section{Introduction}

$\mathrm{CO}_{2}$ emission and noise pollution are the two elements significantly related with the increasing number of vehicles on the road. $\mathrm{CO}_{2}$ is one of greenhouse gases (GHGs) in which a distint increase in the atmosphere will give a distinct threat to the climate change [1]. It was observed that concentration of $\mathrm{CO}_{2}$ in the atmosphere has been increased significantly during last 150 years. In 2016, the average concentration of CO2 was $40 \%$ higher than in the mid-1800s [2,3]. According to [4], transportation sector is the main source of $\mathrm{CO}_{2}$ emissions [5] as almost ninety-five percent of the world's transportation energy comes from petroleum-based fuels [5,6] like gasoline and diesel. Meanwhile, noise pollution is the threat for community health that can lead to several non-auditory effect[7].

Several steps have been taken to decrease the $\mathrm{CO}_{2}$ emissions and noise pollution in the transportation sector. These include the transport management like automatic traffic control system that made the traffic flow smooth and energy-source shifted green fuels such as hybrid and solar driven [8,9]. However, these may not sufficient and in this regard, the concept of CFD (CFD) has been introduced to minimize the energy consumption, $\mathrm{CO}_{2}$ emission and noise pollution [10].

CFD is a term which means, restrict the certain area for any kind of transport where it considered to be necessary for a definite time. CFD is organized in various cities of the world every year in the month of September with the goal of spreading the awareness about environmental concerns and global warming. It discourages use of cars and encourages the use of public transport [11] and so far has shown a good impact on the betterment of the environment and spreading awareness. Universiti Teknologi Malaysia has also taken an initiative by organizing the car-free day on the campus to make atmosphere clean. It is an environment-friendly initiative which is assisting to promote the awareness about the importance of CFD and its contribution towards sustainable developments.

This study aims to determine the impact of the car-free day on building environment. The objectives of the study are to; determine the variation of traffic volume, assess the $\mathrm{CO}_{2}$ concentration and noise level variation, and evaluate the impact of traffic volume variation on $\mathrm{CO}_{2}$ concentration and noise level in building. Two different locations in UTM are selected; One inside the car-free zone while other is outside of it. The data assessment for both cases is critically analyzed and elucidated the future perspective of the car-free approach in UTM and also nationwide in Malaysia.

\section{Methodology}

In this study, two different sites have been selected; the first site is the building of Faculty of Built Environment (BE) and the second is the Faculty of Electrical Engineering (E) shown in Fig. 1. Site BE is situated in car-free zone while $E$ is situated just outside of carfree zone. The point measurement for this study were in the foyer of each building. Building BE is attached to a one-way road which links the vehicle coming from the main entrance of UTM to the rest of the locations in the UTM. On the other hand, Site E is situated just outside of the car-free zone at two adjacent roads which are Jalan Lingkaran Ilmu and Jalan Kempas. 


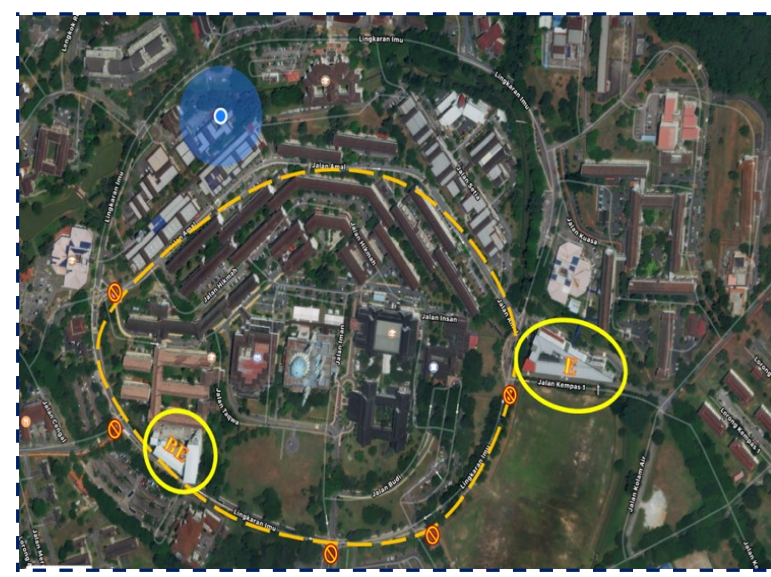

(a) Top view of selected sites BE and E

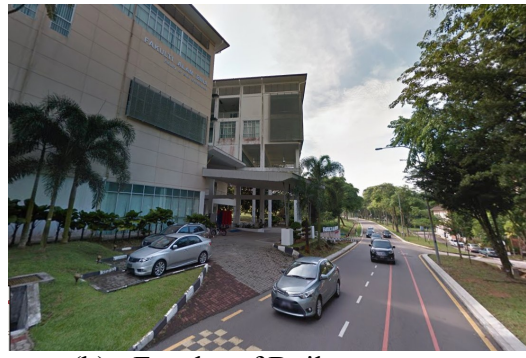

(b) Faculty of Built Environment(BE)

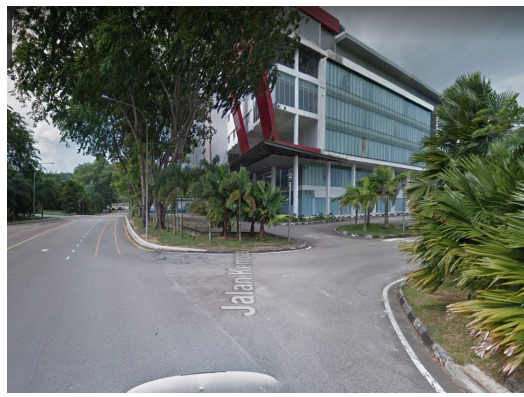

(c) Faculty of Electrical Engineering

Fig. 1. Site selection.

\subsection{Data Collection}

Data of traffic volume, $\mathrm{CO}_{2}$ concentration and noise level were recorded from the start of CFD i.e 8:00 am -3:00 pm at each location. The concentration of CO2 (ppm) were recorded by using a digital Thermo-hygrometer (Model: M0198132S). Measuring range of this instrument is 0 to $9,999 \mathrm{ppm}$ with a CO2 accuracy of $\pm 5 \%$ of the reading. This instrument was installed at foyer area of buildings $\mathrm{BE}$ and $\mathrm{E}$ and attached to a data logger. The data logger records reading after an interval of five seconds within the range of 7 hours CFD. The digital Noise Meter (Model: WS1361) was utilized for noise measurement with unit $\mathrm{dBA}$. Measuring range of this device is between 30 to $130 \mathrm{~dB}$, whereas accuracy is $\pm 1.5 \mathrm{~dB}$. This instrument was also attached with data logger which records readings of every second for 7 hours.

Traffic volume were recorded by using manual method which was manual traffic counting. This method is most commonly practiced in order to obtain the number of individual types of vehicles such as car, bus, lorry etc accurately. In this method, multiple observers recorded the number of vehicles types passing through a certain point. For location BE a point was selected for counting the vehicle at Jalan Lingkaran Ilmu in front of BE. Similarly, for location E, three points were used for counting the traffic from Jalan Lingkaran Ilmu (N24), Jalan Kempas (KP) and Jalan Kempas-Ilmu, respectively.

\subsection{Data Analysis}

Descriptive analysis for three variables such as traffic volume, $\mathrm{CO}_{2}$ concentration and noise level, and their variation between CFD and NCFD and were all analysed. The significant 
of these variables change due to CFD were tested by using T-test if the data were normal and Wilcoxon Signed Rank was used if vice versa. For noise level variation, the significance changes are also characterised by the rule of thumb; a $3 \mathrm{dBA}$ change is considered discernible; a $5 \mathrm{dBA}$ change is clearly discernible; and a $10 \mathrm{dBA}$ change louder is perceived as a doubling or halving of volume, respectively [12]. For $\mathrm{CO}_{2}$, comparison with the Threshold Limit Value for 8-hour time-weighted-average exposures to $\mathrm{CO}_{2}$ is 5,000 ppm were made. Currently, the American Society of Heating, Refrigeration, and Air conditioning Engineers (ASHRAE) suggested the maximum is $1000 \mathrm{ppm}$ for human comfort[13]. Tsai, Lin, and Chan [14] shows that workers exposed to indoor $\mathrm{CO}_{2}$ levels greater than $800 \mathrm{ppm}$ were likely to report more eye irritation or upper respiratory symptoms [15]. Finally, the traffic composition were investigated which may significantly affect the $\mathrm{CO}_{2}$ and noise level variation by using the simple and multiple regression analysis with $\mathrm{R}^{2}$ and ANOVA test with significant level of $5 \%$. According to previous research, a rough rule of thumb for $\mathrm{R}^{2}$ of $0.25,0.50$ and 0.75 are weak, moderate and substantial respectively[16].

\section{Results and discussions}

CFD executed in Universiti Teknologi Malaysia has changed the traffic flow in the campus areas. The traffic from main university entrance are prohibited to get to campus through Jalan Universiti except the granted vehicles such as electric and hybrid vehicles, and public transport such as buses, express postal van etc. Other vehicles are diverted to the Lengkuk Universiti road which is linked with outside of CFD zone where Building of Faculty Electric Engineering (E) is situated. Fig. 2 shows the flow of vehicles during CFD. It can be seen that to avoid restricted road, many vehicles used Jalan KP and small road in front of Faculty of Electrical Building to proceed to unrestricted Jalan Lingkaran Ilmu (N24) to reach other buildings.

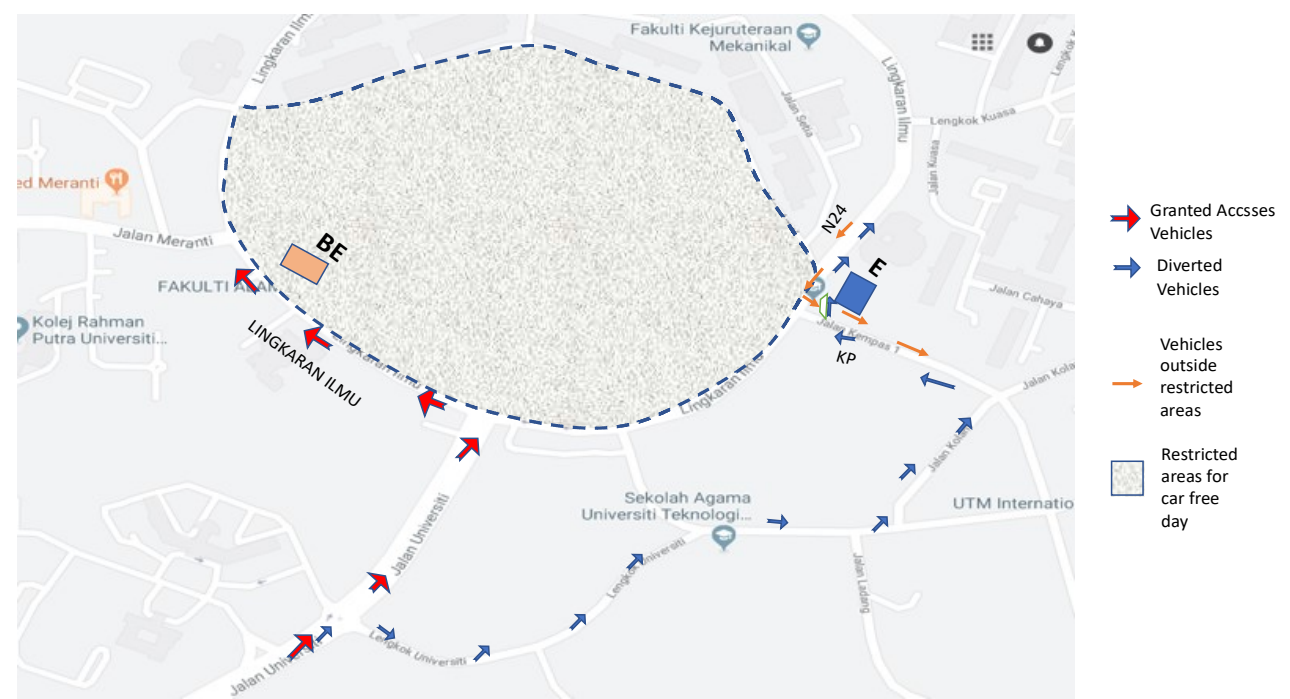

Fig. 2. Traffic flow during CFD.

\subsection{Traffic volume variation}

The total traffic volume during CFD and NCFD at Jalan Lingkaran Ilmu is shown in Fig. 3. When compared with normal day, traffic volume at CFD are reduced more than $80 \%$ with 
average reduction of $729.85 \pm 207.95$ vehicle/hour. The highest reduction is $94 \%$ during 12 to $1 \mathrm{pm}$ while the lowest is at $2-3 \mathrm{pm}$ with $81.68 \%$. On the other hand, the total of traffic volume at Jalan N24 and Jalan KP is shown in Fig. 4. It can be expected that the reduction in Jalan Lingkaran Ilmu has increased the Jalan KP as this is the easiest way to proceed to the other buildings at unrestricted Jalan Lingkaran Ilmu. The average increase is $249.14 \pm 212.63$ vehicle/hour with highest total volumes increase is $82 \%$ at 11 am to $12 \mathrm{pm}$. Statistically, the distribution of traffic volume and it's reduction or increase for all roads follow the normal distribution when the test of Shapiro-Wilk show $p>0.05$. Parametric test by using T-test showed that the variation of traffic volume between CFD and NCFD for both places are significant, $\mathrm{P}<0.05$ (Table 1). Thus, statically CFD reduced the traffic volume at Jalan Lingkaran Ilmu with $\mathrm{p}=0.000$ while increased the traffic volume at Jalan N24 and KP with $\mathrm{p}=0.02$.

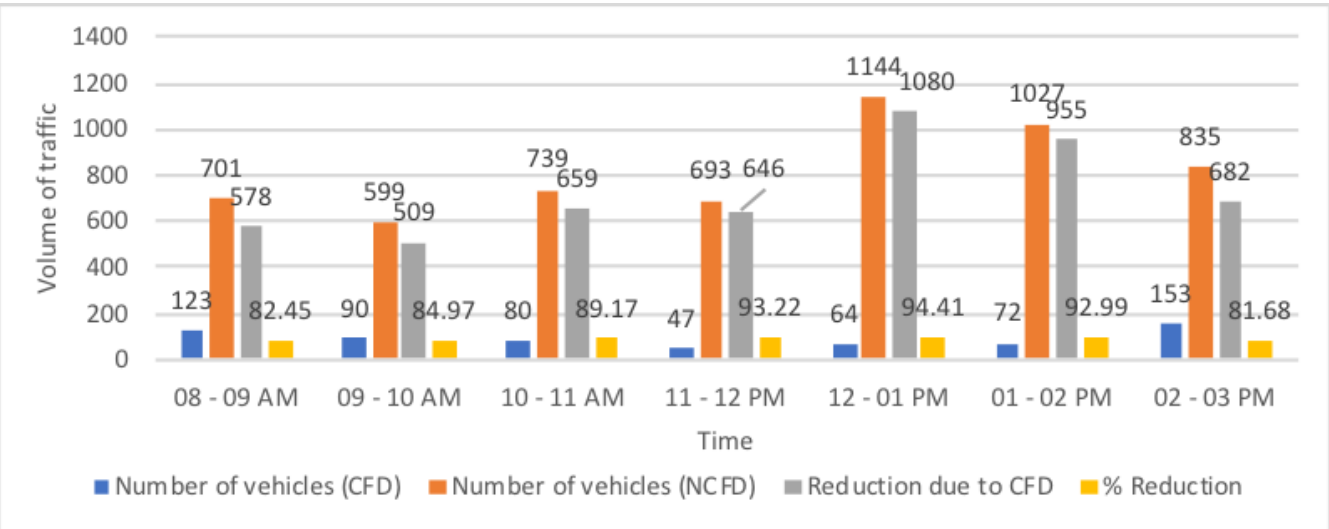

Fig. 3. Variation of traffic volume/hour during CFD and non-CFD at Jalan Lingkaran Ilmu.

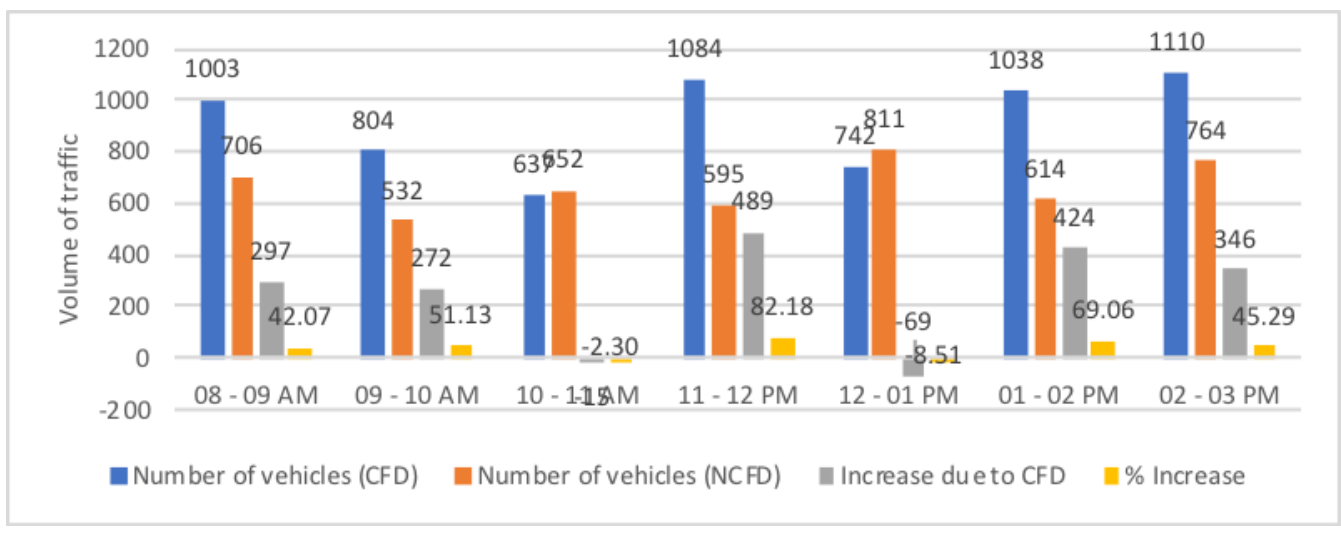

Fig. 4. Variation of traffic volume/hour during CFD and non-CFD at Jalan N24 and Jalan KP. 
Table 1. Average traffic volume, normality test and T-test.

\begin{tabular}{|c|c|c|c|c|c|c|}
\hline & $\begin{array}{l}\text { Jalan } \\
\text { Lingkaran } \\
\text { Ilmu- } \\
\text { CFD } \\
\text { (A) }\end{array}$ & $\begin{array}{c}\text { Jalan } \\
\text { Lingkaran } \\
\text { Ilmu-NCFD } \\
\text { (B) }\end{array}$ & $\begin{array}{l}\text { Jalan } \\
\text { KP + } \\
\text { N24- } \\
\text { CFD } \\
\text { (C) }\end{array}$ & $\begin{array}{l}\text { Jalan KP + } \\
\text { N24-NCFD } \\
\text { (D) }\end{array}$ & $\begin{array}{l}\text { (A)- } \\
\text { (B) }\end{array}$ & (C)-(D) \\
\hline $\begin{array}{l}\text { Mean of traffic } \\
\text { volume }\end{array}$ & 89.85 & 819.71 & 916.85 & 667.71 & 729.85 & 249.14 \\
\hline $\begin{array}{l}\text { Std. Deviation of } \\
\text { traffic volume }\end{array}$ & 36.53 & 197.37 & 186.62 & 98.40 & 207.95 & 212.63 \\
\hline \multicolumn{7}{|c|}{ Normality test by Shapiro-Wilk } \\
\hline Statistic & .934 & .904 & .891 & .975 & & \\
\hline df & 7 & 7 & 7 & 7 & & \\
\hline Sig. & .584 & .357 & .277 & .933 & & \\
\hline \multicolumn{7}{|c|}{ T-test } \\
\hline $\mathrm{t}$ & & & & & -9.28 & 3.10 \\
\hline df & & & & & 6 & 6 \\
\hline Sig. (2-tailed) & & & & & .00 & .02 \\
\hline
\end{tabular}

Fig. 5 shows the composition of traffic consist of cars, busses, lorries, motorcycles and others such as van during CFD and NCFD at Jalan Lingkaran Ilmu. The distribution of cars, busses, lorries, motorcycles and others follow normal distribution as shown by the test of Shapiro-Wilk show $\mathrm{p}>0.05$ except for the other category. During NCFD cars has highest composition with mean of $637 \pm 167.84$ followed by bus, lorry and others with $21.35 \pm 8.31$, $8.00 \pm 2.75,148.00 \pm 48.45$ and $4.57 \pm 4.03$, respectively. According to T-test only volume of car, lorry and motorcycles in each hour of CFD significantly reduced the volume (Table 2). Nevertheless, CFD o not reduce significantly the volume of buses each hour $(\mathrm{p}=0.075)$. There are also significant differences in variation of volume for other category between CFD and NCFD when tested by using non-parametric test of Wilcoxon Signed Ranked.

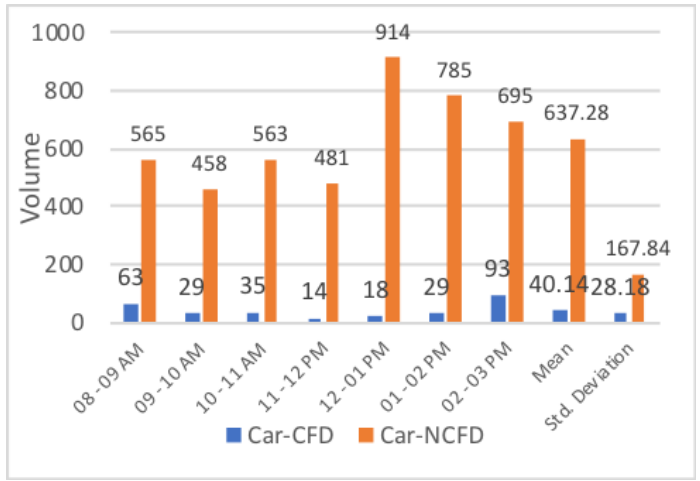

(a) Car

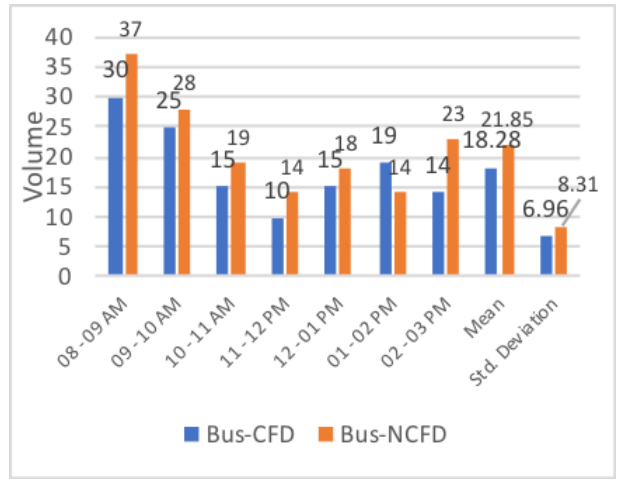

(b) Bus 


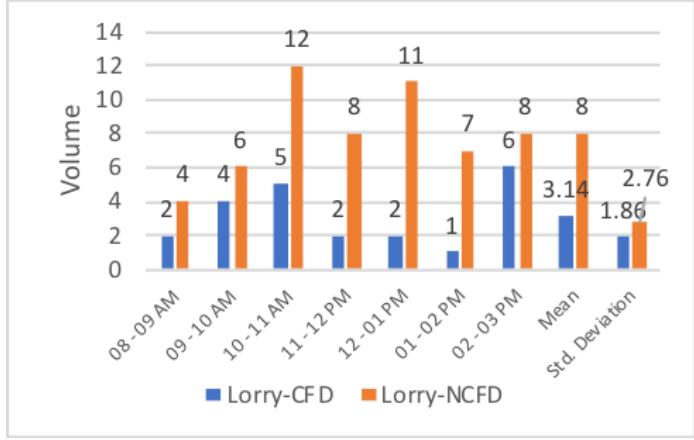

(c) Lorry

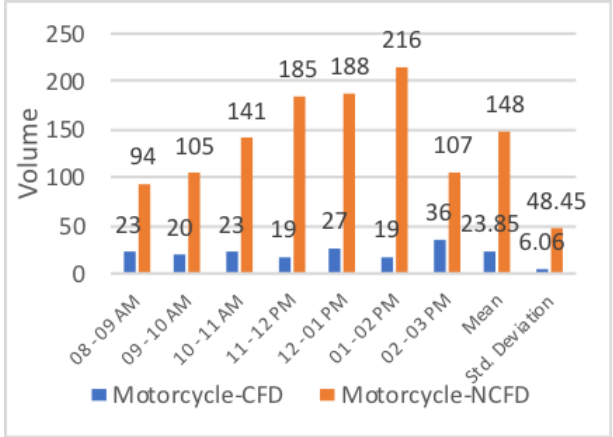

(d) Motorcycles

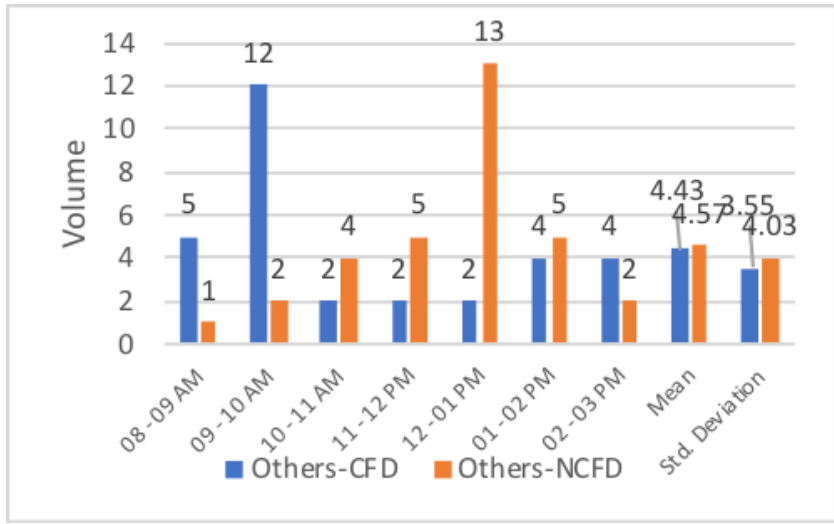

(e) others

Fig. 5. Composition of traffic changes between CFD and NCFD at Jalan Lingkaran Ilmu in front of BE.

Table 2. Significant test for traffic composition changes due to CFD.

\begin{tabular}{lrrrcrr}
\hline $\begin{array}{l}\text { Changes of } \\
\text { volume }\end{array}$ & Mean & $\begin{array}{r}\text { Std. } \\
\text { Deviation }\end{array}$ & $\begin{array}{r}\text { Std. Error } \\
\text { Mean }\end{array}$ & $\mathrm{t}$ & $\mathrm{df}$ & $\begin{array}{r}\text { Sig. (2- } \\
\text { tailed) }\end{array}$ \\
Cars & 597.14 & 170.10 & 64.29 & 9.28 & 6 & .000 \\
\hline Buses & 3.57 & 4.39 & 1.65 & 2.15 & 6 & .075 \\
Lorries & 4.85 & 2.85 & 1.07 & 4.50 & 6 & .004 \\
\hline Motorcycles & 124.14 & 51.05 & 19.29 & 6.43 & 6 & .001
\end{tabular}

Fig. 6 shows the composition of traffic during NCFD and CFD at Jalan N24. ShapiroWilk also shows that the distribution of traffic composition follow normal distribution as $p>0.05$ except for the other category (Table 3 ). During CFD it can be seen that the number of cars cruising on N24 fluctuated with high increase at 11 am-12 pm and 1-2 pm. Overall, the average volume of cars per hour is $372.42 \pm 127.02$ during CFD compared with NCFD with 363.14 \pm 84.07 , however the increased is not significant according to $\mathrm{T}$ test $(\mathrm{p}=0.89)$ (Table 3$)$. The scenario also happen to the number of lorries and busses with the variation are not statistically significant $(\mathrm{p}>0.05)$. The trend of motorcycles are vice- 
versa with in each hour the average is $125.85 \pm 41.79$ during CFD and $92.42 \pm 42.61$ during NCFD with the changes happen significantly $(\mathrm{p}=0.004)$. Again, there are significant differences in variation of volume for other category between CFD and NCFD when tested by using non-parametric test of Wilcoxon Signed Ranked.

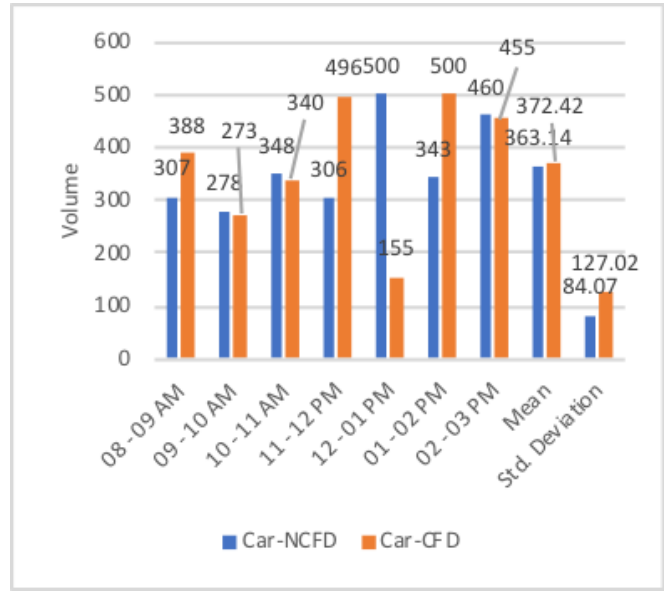

(a) $\mathrm{Car}$

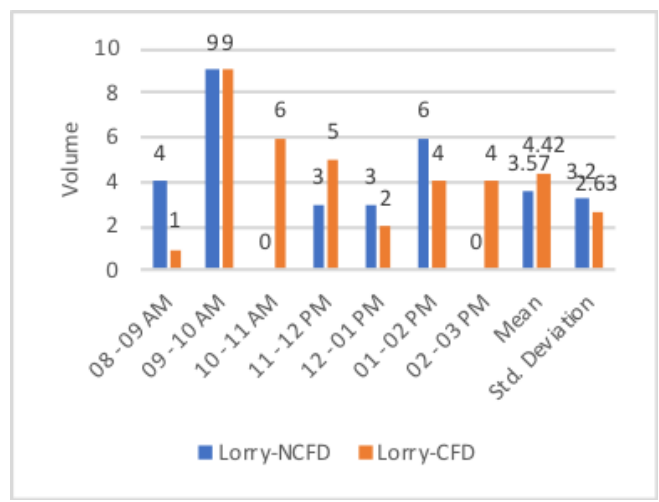

(c) Lorry

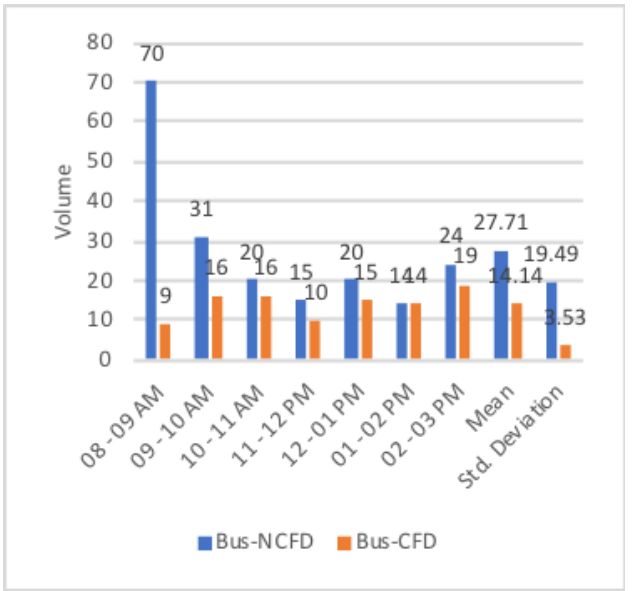

(b) Bus

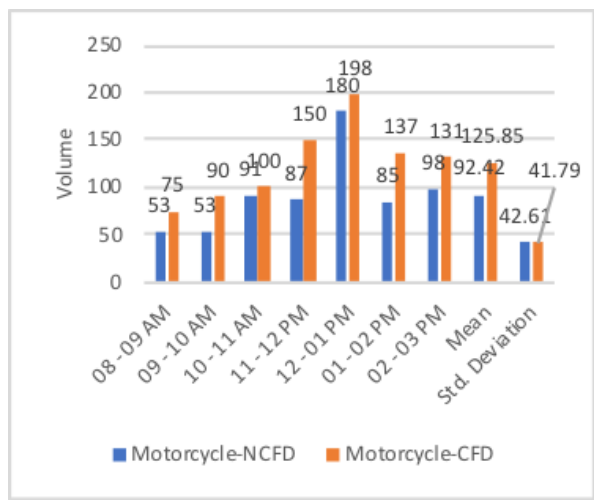

(d) Motorcycles

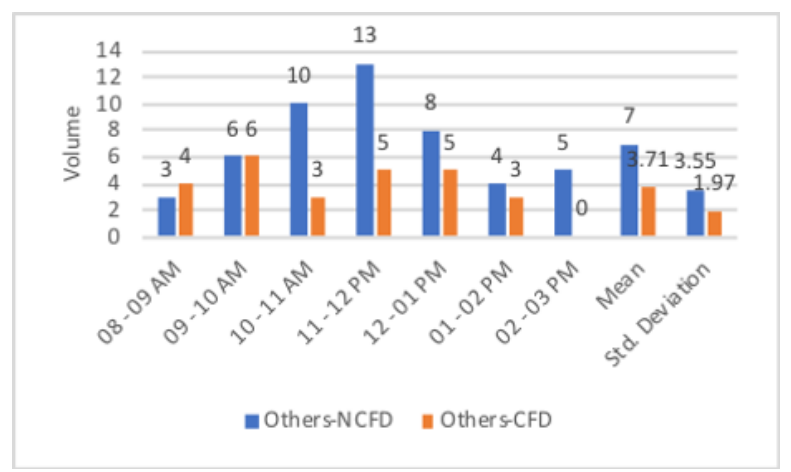

(e) Other

Fig. 6. Composition of traffic changes during CFD and NCFD at Jalan N24. 
Table 3. Significant test for traffic composition changes due to CFD at Jalan N24.

\begin{tabular}{lrrrrrr}
\hline $\begin{array}{l}\text { Changes of } \\
\text { volume }\end{array}$ & Mean & $\begin{array}{r}\text { Std. } \\
\text { Deviation }\end{array}$ & $\begin{array}{r}\text { Std. Error } \\
\text { Mean }\end{array}$ & $\mathrm{t}$ & $\mathrm{df}$ & $\begin{array}{r}\text { Sig. (2- } \\
\text { tailed) }\end{array}$ \\
Cars & -9.28 & 175.99 & 66.51 & -.14 & 6 & .894 \\
\hline Buses & 13.57 & 21.39 & 8.08 & 1.67 & 6 & .144 \\
Lorries & -.85 & 3.28 & 1.24 & -.69 & 6 & .516 \\
\hline Motorcycles & -33.42 & 19.13 & 7.23 & -4.62 & 6 & .004
\end{tabular}

Fig. 7 shows the composition of traffic changes between NCFD and CFD at Jalan KP. As the other roads, the distribution of traffic volume of car, bus, lorry and motorcycles are following normal distribution. During CFD, only volume of cars $(280.26 \pm 118.32)$ and motorcycles $(107.71 \pm 16.73)$ each hour exceeded the non CFD. Consequently, the different of each are tested by using t test (Table 4) and showed that only changes of traffic volume of motor cycles $(57.00 \pm 13.82)$ and cars(165.14 \pm 110.05$)$ are statistically significant as $p$ $<0.05$.

\subsection{Carbon Dioxide concentration variation}

Concentration of $\mathrm{CO} 2$ and variation is the first indicator to analyze the environmental impact on $\mathrm{CFD}$ at site $\mathrm{BE}$ and $\mathrm{E}$ (Table 5). At BE, the average of CO2 during NCFD is $419.09 \pm 10.66$ and reduced to $405 \pm 13.47 \mathrm{ppm}$. Both with and without CFD the $\mathrm{CO} 2$ is within the range of typical indoor environment of 350 to 2,500 ppm under the Threshold Limit Value for 8hour time-weighted-average exposures of 5,000 ppm. The reading follow the normal distribution and according to T-test, it can be concluded that there are a statistically significant reduction in $\mathrm{CO}_{2}$ concentration at $\mathrm{BE}$ following the $\mathrm{CFD}$ program $\mathrm{t}(7)=7.36$ $(\mathrm{p}=0.00)$.

At E, it can be seen that during the first 2 hour it remains normal but during the rest of the hour it started increasing rapidly and jumped to $>9999(\mathrm{ppm})$ till $3 \mathrm{PM}$. This value exceeded the ASHRAE thet suggested $\mathrm{CO}_{2}$ maximum is $1000 \mathrm{ppm}$ for human comfort. This uneven increase in reading may occur due to the $\mathrm{CO}_{2}$ accumulation as a result of the high traffic volume and poor ventilation. In the first 3 hours the reading $\mathrm{CO}_{2}$ shows six times more than at the first hour while the increment are more than 30 times. The test of ShapiroWilk test showed these are not normally distributed (Table 6). 


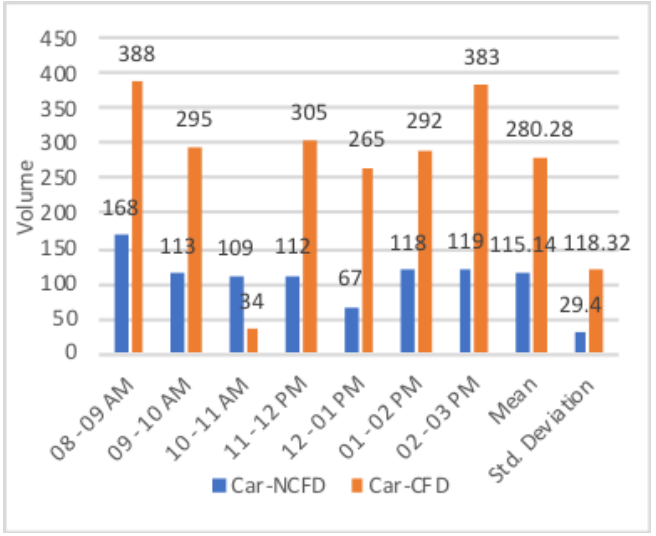

(a) Car

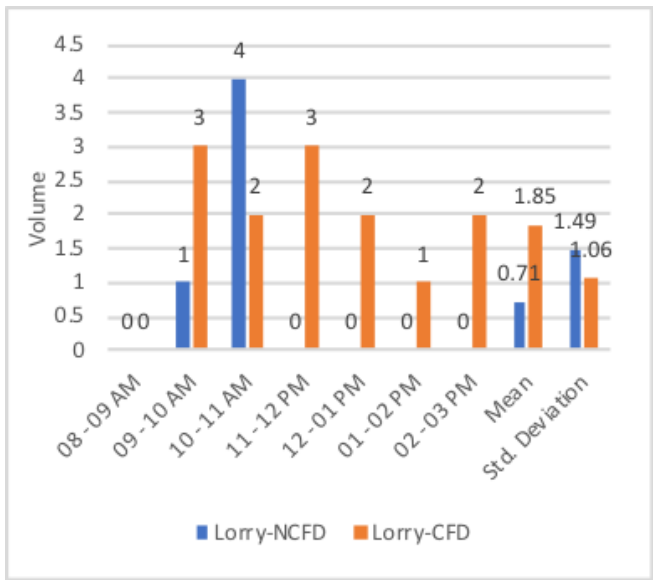

(c) Lorry

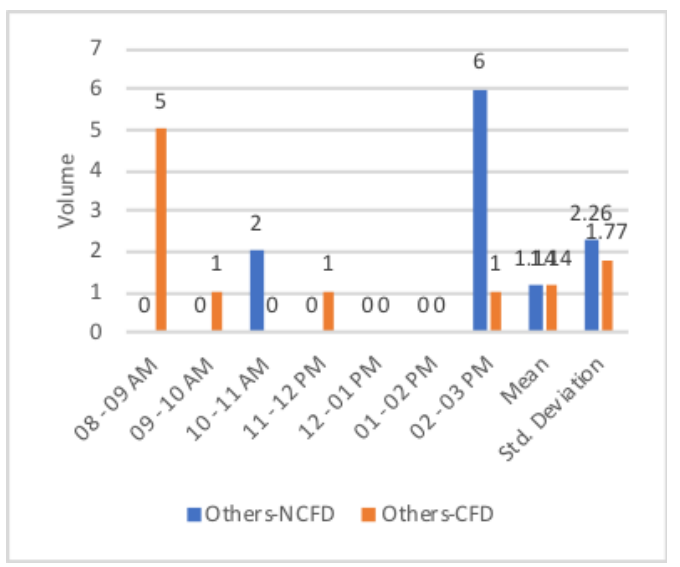

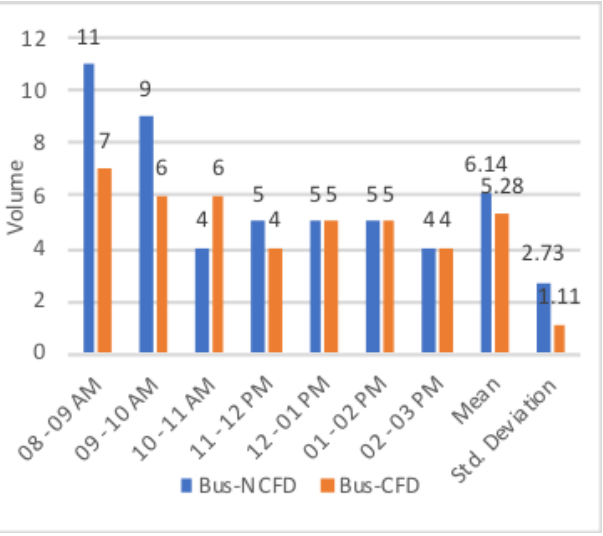

(b) Bus

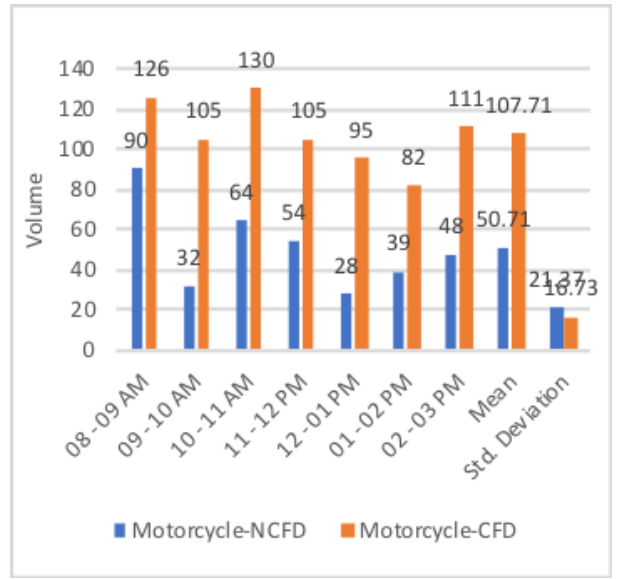

(d) Motorcycles

(e) Other

Fig. 7. Composition of traffic changes during CFD and NCFD at Jalan KP. 
Table 4. Significant test for traffic composition changes due to CFD at Jalan KP.

\begin{tabular}{lrrrrrr}
\hline $\begin{array}{l}\text { Changes of } \\
\text { volume }\end{array}$ & Mean & $\begin{array}{r}\text { Std. } \\
\text { Deviation }\end{array}$ & $\begin{array}{r}\text { Std. Error } \\
\text { Mean }\end{array}$ & $\mathrm{t}$ & $\mathrm{df}$ & $\begin{array}{r}\text { Sig. (2- } \\
\text { tailed) }\end{array}$ \\
Cars & -165.14 & 110.05 & 41.59 & -3.97 & 6 & .007 \\
\hline Buses & .85 & 2.03 & .76 & 1.11 & 6 & .308 \\
Lorries & -1.14 & 1.67 & .63 & -1.80 & 6 & .121 \\
\hline Motorcycles & -57.00 & 13.82 & 5.22 & -10.91 & 6 & .000
\end{tabular}

Table 5. Hourly average concentration of $\mathrm{CO}_{2}$ at Location $\mathrm{BE}$ and $\mathrm{E}$.

\begin{tabular}{|c|c|c|c|c|c|c|}
\hline Time & $\begin{array}{c}\mathrm{CO2} \text { at BE } \\
\text { during NCFD } \\
(\mathrm{ppm})\end{array}$ & $\begin{array}{c}\mathrm{CO2} \text { at BE } \\
\text { during CFD } \\
\text { (ppm) }\end{array}$ & Reduction & $\begin{array}{c}\text { CO2 at } \\
\text { E during } \\
\text { NCFD } \\
\text { (ppm) }\end{array}$ & $\begin{array}{c}\text { CO2 at } \\
\text { E during } \\
\text { CFD } \\
\text { (ppm) }\end{array}$ & Increase \\
\hline $08-09$ AM & 433.44 & 430.59 & 2.85 & 446.13 & 540 & 93.87 \\
\hline $09-10 \mathrm{AM}$ & 433.02 & 415.67 & 17.35 & 449.14 & 756.23 & 307.09 \\
\hline $10-11 \mathrm{AM}$ & 416.31 & 402.42 & 13.89 & 422.81 & 3349.89 & 2927.08 \\
\hline $11-12$ PM & 417.89 & 402.73 & 15.16 & 428.14 & $>9999$ & - \\
\hline $12-01$ PM & 417.07 & 400.82 & 16.25 & 426.01 & $>9999$ & - \\
\hline $01-02$ PM & 411.34 & 396.01 & 15.33 & 413.08 & $>9999$ & - \\
\hline $02-03$ PM & 404.61 & 390.44 & 14.17 & 401.24 & $>9999$ & - \\
\hline Mean & 419.09 & 405.52 & 13.57 & 426.65 & & \\
\hline Std. Deviation & 10.66 & 13.47 & 4.87 & 16.99 & & \\
\hline
\end{tabular}

Table 6. Normality test of $\mathrm{CO}_{2}$ at Location $\mathrm{BE}$ and $\mathrm{E}$.

\begin{tabular}{llllll}
\hline & Statistic & $\mathrm{df}$ & Statistic & $\mathrm{df}$ & Sig. \\
$\mathrm{CO} 2$ at BE during CFD & .296 & 7 & .897 & 7 & .311 \\
\hline $\mathrm{CO} 2$ at BE during NCFD & .259 & 7 & .897 & 7 & .316 \\
$\mathrm{CO} 2$ at $\mathrm{E}$ during CFD & .356 & 7 & .729 & 7 & .008 \\
\hline $\mathrm{CO} 2$ at $\mathrm{E}$ during NCFD & .179 & 7 & .952 & 7 & .749
\end{tabular}

\subsection{Noise level variation}

The results of variation of sound pressure level at $\mathrm{BE}$ and $\mathrm{E}$ for each hour is shown in Fig. 8. At $\mathrm{BE}$ reduction are highest at two hours from $11 \mathrm{am}$ to $1 \mathrm{pm}$ of more than $6 \mathrm{dBA}$ while least at 8 to 10 am with reduction of $2.3 \mathrm{dBA}$ (not perceptible). Thus overall, CFD reduces the SPL with average of $4.77 \mathrm{dBA}$ and its clearly discernible. Statisticaly, the data at BE and E for both CFD and NCFD and NCFD are normally distributed when tested with Shapiro-Wilk test (Table 7). In contrast, variation of noise level at E due to CFD increases more than $3 \mathrm{dBA}$ at $11-12$ am and 2-3 pm while the other times the increase are not 
perceptible. The t-test on compared mean showed that the reduction of noise level at BE and increase of noise level at $\mathrm{E}$ are statistically significant (Table 7).

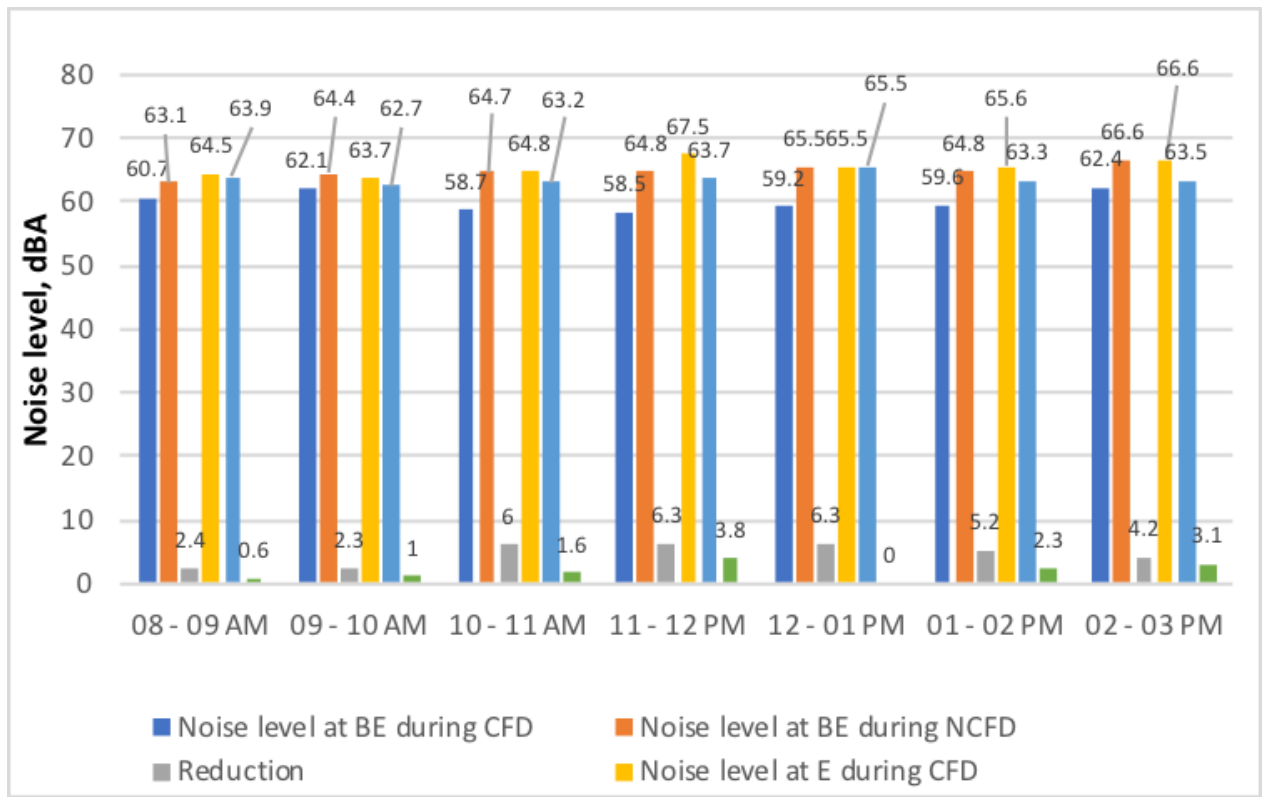

Fig. 8. Hourly sound Pressure Level at Location BE and E.

Table 7. Significant test on sound Pressure Level at Location BE and E.

\begin{tabular}{|c|c|c|c|c|c|c|}
\hline & $\begin{array}{l}\text { Noise level } \\
\text { at BE } \\
\text { during CFD }\end{array}$ & $\begin{array}{l}\text { Noise level at } \\
\text { BE during } \\
\text { NCFD }\end{array}$ & Reduction & $\begin{array}{c}\text { Noise level } \\
\text { at } E \\
\text { during } \\
\text { CFD }\end{array}$ & $\begin{array}{l}\text { Noise level at } \\
\text { E during } \\
\text { NCFD }\end{array}$ & Increase \\
\hline Mean & 60.17 & 64.84 & 4.67 & 65.45 & 63.68 & 1.77 \\
\hline $\begin{array}{c}\text { Std. } \\
\text { Deviation }\end{array}$ & 1.59 & 1.06 & 1.74 & 1.28 & 0.88 & 1.37 \\
\hline \multicolumn{7}{|c|}{ Normality test } \\
\hline Statistic & .887 & .943 & & .978 & .857 & \\
\hline df & 7 & 7 & & 7 & 7 & \\
\hline Sig. & .262 & .668 & & .948 & .143 & \\
\hline \multicolumn{7}{|c|}{ T-test } \\
\hline $\mathbf{t}$ & & & 7.06 & & & 3.41 \\
\hline df & & & 6 & & & 6 \\
\hline $\begin{array}{l}\text { Sig. (2- } \\
\text { tailed) }\end{array}$ & & & 0.00 & & & 0.014 \\
\hline
\end{tabular}




\subsection{Impact of traffic volume variation on noise level}

Table 8 and 9 show the analysis of impact of traffic volume on noise level by investigating the strength of relationship between traffic volume as predictor of noise level. Noise level at BE during CFD has significant relationship with traffic volume with ANOVA analysis $\mathrm{p}<0.05$ which is not for NCFD. Simple linear regression shows that $\mathrm{R}^{2}=0.644$ (moderate to substantial) in which 64 percent of traffic volume at Jalan Lingkaran Ilmu describe the noise level during CFD. ANOVA analysis also shows the significant $p=0.03$ implies that volume of traffic give an impact on noise level. Investigation by using correlation and multiple regression with volume of car, bus, lorry, motorcycles as independent variables showed that reduction of noise level during CFD significantly depend on reduction of volume of lorry $(\mathrm{p}=0.007)$ (Table 8). At $\mathrm{E}$, during CFD, noise level is significantly influenced by; first is traffic total volume of motorcycles and total volume of $\operatorname{cars}(\mathrm{p}=0.035)$ and second by volume of bus coming from Jalan KP $(\mathrm{p}=0.010)$ (Table 9). Thus, according to $\mathrm{R}^{2}$ value , the first has the greatest impact as the $\mathrm{R}^{2}$ is higher. Whilst, during normal day, noise level only statistically influenced by either total volume of motorcycles $(\mathrm{p}=0.006)$ or volume of motorcycles coming from Jalan N24.

Table 8. Regression analysis on relationship between noise Level and traffic volume at Location BE.

\begin{tabular}{|c|c|c|c|c|c|c|}
\hline Dependent & Predictor & $\mathrm{R}$ & $\mathrm{R}^{2}$ & $\begin{array}{c}\text { Adjusted } \\
\text { R } \\
\text { Square }\end{array}$ & $\begin{array}{c}\mathrm{F} \\
\text { Change }\end{array}$ & $\begin{array}{c}\text { Sig. F } \\
\text { Change }\end{array}$ \\
\hline \multirow[t]{2}{*}{$\begin{array}{c}\text { Noise level } \\
\text { during NCFD }\end{array}$} & $\begin{array}{l}\text { Volume of traffic } \\
\text { during NCFD }\end{array}$ & $.439^{a}$ & .193 & .031 & 1.194 & .324 \\
\hline & $\begin{array}{c}\text { Volume of traffic } \\
\text { during CFD } \\
\text { (VBE@CFD) }\end{array}$ & $.803^{\mathrm{a}}$ & .644 & 0.573 & 9.057 & .030 \\
\hline $\begin{array}{c}\text { Decrease } \\
\text { noise level } \\
\text { due to CFD }\end{array}$ & $\begin{array}{l}\text { Reduction of volume } \\
\text { of lorries(DL) }\end{array}$ & $0.891^{\mathrm{a}}$ & 0.793 & .752 & 19.187 & $0.007^{\mathrm{b}}$ \\
\hline
\end{tabular}

Table 9. Regression analysis on relationship between noise Level and traffic volume at Location E.

\begin{tabular}{|c|c|c|c|c|c|c|}
\hline Dependent & Predictor & $\mathrm{R}$ & $\begin{array}{l}\mathrm{R} \\
\text { Square }\end{array}$ & $\begin{array}{l}\text { Adjusted } \\
\text { R Square }\end{array}$ & $\begin{array}{l}\text { F } \\
\text { Change }\end{array}$ & $\begin{array}{l}\text { Sig. F } \\
\text { Change }\end{array}$ \\
\hline \multirow[t]{2}{*}{$\begin{array}{l}\text { Noise level } \\
\text { during CFD }\end{array}$} & $\begin{array}{l}\text { Total volume of } \\
\text { motorcycles } \\
\text { (TOTVBIK) and total } \\
\text { volume of cars } \\
\text { (TOTVC)- at Jln KP } \\
\text { and N24 }\end{array}$ & $.902^{\mathrm{a}}$ & .814 & .721 & 8.755 & $.035^{\mathrm{b}}$ \\
\hline & $\begin{array}{l}\text { Volume of Bus } \\
\text { coming from Jalan } \\
\text { KP(BUS@ECFDKP) }\end{array}$ & $.875^{\mathrm{a}}$ & .765 & .718 & 16.268 & $.010^{\mathrm{b}}$ \\
\hline \multirow[t]{2}{*}{$\begin{array}{l}\text { Noise level } \\
\text { during NCFD }\end{array}$} & $\begin{array}{l}\text { Total volume of } \\
\text { motorcycles during } \\
\text { NCFD } \\
\text { (TOTVNCFDBIK) }\end{array}$ & $.899^{\mathrm{a}}$ & .808 & .770 & 21.067 & $.006^{\mathrm{b}}$ \\
\hline & $\begin{array}{l}\text { Volume of } \\
\text { motorcycles coming } \\
\text { from Jalan N24 } \\
\text { (BIKE@ENFCDN24) }\end{array}$ & $.845^{\mathrm{a}}$ & .714 & .656 & 12.458 & $.017^{\mathrm{b}}$ \\
\hline
\end{tabular}




\subsection{Impact of traffic volume variation on $\mathrm{CO} 2$ concentration}

The analysis of impact of traffic volume on $\mathrm{CO}_{2}$ is also identified by investigating the strength of relationship between traffic volume as predictor of $\mathrm{CO}_{2}$ concentration. It is clear that relationship between amount of $\mathrm{CO}_{2}$ during CFD with traffic volume is very weak $\left(\mathrm{R}^{2}=0.12\right)$. Further investigation by using correlation between traffic composition and $\mathrm{CO}_{2}$ concentration as shown in Table 10. There is good correlation between $\mathrm{CO}_{2}$ concentration and volume of bus (BUS@BECFD) and moderate correlation with motorcylces and others, ad weak correlation with volume of car. Thus multiple regression analysis is performed and obtained that moderate and substantial relationship occurs between $\mathrm{CO}_{2}$ and volume of bus cruising on Jalan Lingkaran Ilmu in front of building $B E$ with $\mathrm{R}^{2}=0.69$ and $\mathrm{p}=0.020$.

Table 10. Correlation between $\mathrm{CO} 2$ with traffic composition at $\mathrm{BE}$.

\begin{tabular}{|l|r|r|r|r|r|r|}
\hline & \multicolumn{1}{|l|}{$\begin{array}{l}\text { CO2 } \\
\text { during } \\
\text { CFD }\end{array}$} & \multicolumn{1}{l|}{$\begin{array}{l}\text { Volume } \\
\text { of car }\end{array}$} & \multicolumn{1}{l|}{$\begin{array}{l}\text { Volume of } \\
\text { bus }\end{array}$} & $\begin{array}{l}\text { Volume of } \\
\text { lorry }\end{array}$ & $\begin{array}{l}\text { Volume of } \\
\text { motorcycles }\end{array}$ & $\begin{array}{l}\text { Volume of } \\
\text { others }\end{array}$ \\
\hline $\begin{array}{l}\text { CO2 during } \\
\text { CFD }\end{array}$ & 1 & -.017 & $.832^{*}$ & -.264 & -.400 & .444 \\
\hline $\begin{array}{l}\text { Volume of } \\
\text { car }\end{array}$ & -.017 & 1 & .225 & .586 & $.761^{*}$ & .068 \\
\hline $\begin{array}{l}\text { Volume of } \\
\text { bus }\end{array}$ & $.832^{*}$ & .225 & 1 & -.183 & -.231 & .641 \\
\hline $\begin{array}{l}\text { Volume of } \\
\text { lorry }\end{array}$ & -.264 & .586 & -.183 & 1 & .636 & .165 \\
\hline $\begin{array}{l}\text { Volume of } \\
\text { motorcycles }\end{array}$ & -.400 & $.761^{*}$ & -.231 & .636 & 1 & -.205 \\
\hline $\begin{array}{l}\text { Volume of } \\
\text { others }\end{array}$ & .444 & .068 & .641 & .165 & -.205 & 1 \\
\hline
\end{tabular}

\section{Conclusions}

The implementation of CFD at UTM has two impacts on building environment. First is good impact in which CFD reduces traffic volumes, $\mathrm{CO}_{2}$ and noise level at Building $\mathrm{BE}$ that located in car free zone. The reduction of $\mathrm{CO}_{2}$ is $13.57 \pm 4.87 \mathrm{ppm}$ per hour and the reduction of noise level is $4.7 \pm 1.74 \mathrm{dBA}$, both as statically significant reduction. As expected, noise level is significantly correlated with the total volume of traffic on Jalan Lingkaran Ilmu and when the reduction of noise level is concerned, it is significantly related with decrease of volume of lorries on Jalan Lingkaran Ilmu. The concentration of $\mathrm{CO} 2$ is significantly governed by the volume of the bus. Second is the adverse impact which is the significant increase in traffic volume from the Jalan KP and Jalan N24 which dominantly characterized by car and motorbikes. These results in increase in noise level as much as $1.77 \pm 1.37 \mathrm{dBA}$. Moreover, at foyer of building E, CO2 increase more than 9999 ppm after the first 3 hours of CFD till the end of CFD. This make the foyer of building is considered as sick during CFD and need more proper ventilation. In general, result from this study shows that CFD improve the environment in building located at CFD zone but worsen the building environment in NCFD.

The study was funded by GUP Q.J130000.2522.15H28, GUP Q.J130000.2522.19H76, and FRGS R.J130000.7822.4F887 which supported by Research Management Centre, Universiti Teknologi Malaysia. These supports are highly appreciated. 


\section{References}

1. C. Azar, K. Lindgren, B.A. Andersson, Energy Policy, 31(10), 961-976 (2003)

2. R. Quadrelli, S. Peterson, Energy policy, 35(11), 5938-5952 (2007)

3. D. Ospina, S. Zapata, M. Castañeda, I. Dyner, A. J. Aristizabal, N. Escalante, International Journal of Electrical and Computer Engineering (IJECE), 8(3) (2018)

4. T. Berntsen, N.L.B. Zhenlin Chen, A. Chidthaisong, P. Friedlingstein, J. M. Gregory, G. C. Hegerl, M. Heimann, B. Hewitson, B. J. Hoskins, F. Joos, J. Jouzel, V. Kattsov, IPCC, 2007: Summary for Policymakers. In: Climate Change 2007: The Physical Science Basis. Contribution of Working Group I to the Fourth Assessment Report of the Intergovernmental Panel on Climate Change [Solomon, S., D. Qin, M. Manning, Z. Chen, M. Marquis, K.B. Averyt, M.Tignor and H.L. Miller (eds.)]. Cambridge University Press, Cambridge, United Kingdom and New York, NY, USA. (20

5. L. Suganthi, A.A. Samuel, Renewable and sustainable energy reviews, 16(2),1223$1240(2012)$

6. M. Asif, T. Muneer, Renewable and Sustainable Energy Reviews, 11(7),1388-1413 (2007)

7. S. A. Stansfeld, M. P. Matheson, British Medical Bulletin, 68(1), 243-257 (2003)

8. B. Yang, K. M. Zhang, W. D. Xu, S. Zhang, S. Batterman, R. W. Baldauf, P. Deshmukh, R. Snow, Y. Wu, Q. Zhang, Z. Li, and X. Wu, Environmental science \& technology 52 (8), 4574-4582 (2018)

9. B. V, Wee, K. Maat, C. De Bont, European Planning Studies, 20(1), 95-110 (2012)

10. H. Fathabadi, Plug-in Hybrid Electric Vehicles (PHEVs): Replacing Internal Combustion Engine with Clean and Renewable Energy Based Auxiliary Power Sources. IEEE Transactions on Power Electronics (2018).

11. N. Ramie, S. Emami, O.K. Sadaghiyani, Propulsion and power research 3(2). 59-67 (2014)

12. H. Topp, T. Pharoah, Transportation, 21(3), 231-247((1994)

13. J. L. Darbyshire, J. D. Young, Critical Care, 17(187) (2013)

14. C. A. Erdmann, K. C. Steiner, M. G. Apte, Proceedings: Indoor Air (2002)

15. D. H. Tsai, J. S. Lin, C. C. Chan, J Occup Environ Hyg. 9(5) 345-51 (2012)

16. W. W. Low, H. Abdul Rahman, N. Zakaria, Int. J. of Project Mngmnt 33, 917-931 (2015) 